Jurnal Basicedu Volume 3 Nomor 4 Tahun 2019 Halaman 2144-2158

JURNAL BASICEDU

Research \& Learning in Elementary Education

https://jbasic.org/index.php/basicedu

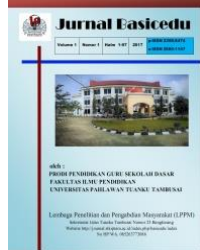

\title{
PENERAPAN PAIKEM GEMBROT UNTUK MENINGKATKAN HASIL BELAJAR SAINS DI SEKOLAH DASAR
}

\author{
Mulyani Sabihi' \\ Sekolah Dasar Negeri Manggarai 09 Pagi, Jakarta , Indonesia ${ }^{1,2,3}$ \\ Email: mulyanisabihi@gmail.com ${ }^{1}$
}

\begin{abstract}
Abstrak
Penerapan ini dilatarbelakangi dengan rendahnya hasil ulangan harian siswa pada pembelajaran sains yang pencapaiannya hanya $50 \%$ telah tuntas KKM, dengan nilai KKM 63. Selain itu dalam pembelajaran di kelas siswa cenderung pasif. Berdasrkan permasalahan tersebut, maka tujuan yang ingin dicapai adalah : memperoleh gambaran tentang perencanaan, pelaksanaan pembelajaran, dan peningkatan hasil belajar melalui penerapan PAIKEM Gembrot di kelas II SD Negeri Manggarai 09 Pagi Kecamatan Tebet Jakarta Selatan. Metode yang digunakan dalam penelitian ini adalah peneltiian Tindakan Kelas (PTK) yang mengadaptasi dalam penelitian ini adalah model Kemmis \& Mc. Taggart dengan tiga siklus. Subjek Penelitian ini adalah siswa kelas II semester II SD Negeri Manggarai 09 Kecematan Tebet JakartaSelatan berjumlah 20 orang. Hasil penelitian dengan penerapan PAIKEM GEMBROT menunjukkan adanya peningkatan proses pembelajaran, terlihat siswa sangat senang dan aktif dalam berpartisipasi dalam pembelajaran. Demikian pula perolehan hasil belajar siswa mengalami peningkatan pada siklus I pertemuan I diperoleh hasil 5\% siswa pada kategori buruk (< 29), 20\% siswa masih berada pada kategori "kurang" (30-49), 40\% kategori "cukup" (50-69), 35\% pada kategori "baik" (70-89), dan 0\% pada kategori "baik sekali" (>90), siklus I pertemuan 2 diperoleh hasil 5\% siswa pada kategori buruk $(<29)$, 20\% siswa masih berada pada kategori "kurang" (30-49), 30\% kategori “cukup" (50-69), 30\% pada kategori "baik" (70-89), dan sisanya 15\% pada kategori "baik sekali" (>90). Siklus II pertemuan I diperoleh hasil 10\% siswa berada pada kategori "kurang" (30-49), 20\% kategori “cukup" (50-69), 50\% pada kategori "baik" (70-89), dan sisanya 20\% pada kategori "baik sekali" (>90). Sedangkan pada siklus II pertemuan 2 peneliti memperoleh hasil $0 \%$ siswa pada ketegori buruk $(<29), 5 \%$ siswa masih berada pada kategori "kurang" $(30-49)$, $25 \%$ kategori "cukup" (50-69), 30\% pada kategori "baik" (70-89), dan sisanya 40\% pada kategori "baik sekali" ( $>90)$. Dengan analisis data tersebut, maka dapat disimpulkan bahwa penerapan PAIKEM GEMBROT dapat dijadikan alternative pembelajaran untuk meningkatkan hasil belajar siswa.
\end{abstract}

Kata Kunci: PAIKEM Gembrot, Hasil belajar, sains

\section{Abstract}

This application is motivated by the low results of daily tests of students in science learning, whose achievements are only $50 \%$ have been completed KKM, with a KKM score of 63. Besides that in learning in class students tend to be passive. Based on these problems, the objectives to be achieved are: obtain a picture of planning, implementation of learning, and improving learning outcomes through the application of PAIKEM Gembrot in grade II SD Negeri Manggarai 09 Pagi, Tebet, South Jakarta. The method used in this research is Classroom Action Research (PTK) which adapted in this study is the Kemmis \& Mc. Taggart with three cycles. The subjects of this study were the second semester students of the second semester at SD Negeri Manggarai 09, Tebet, South Jakarta. The results of research with the application of PAIKEM GEMBROT show an increase in the learning process, it appears that students are very happy and active in participating in learning. Similarly, the acquisition of student learning outcomes has increased in the first cycle of meeting I obtained the results of $5 \%$ of students in the bad category $(<29), 20 \%$ of students are still in the category of "less" $(30-49)$, $40 \%$ of the category of "enough" -69), 35\% in the "good" category (70-89), and $0 \%$ in the "excellent" category (>90), the first cycle of meeting 2 obtained the results of 5\% of students in the bad category (<29), 20\% students are still in the category of "poor" (30-49), $30 \%$ in the category of "enough" (50-69), 30\% in the category of "good" (70-89), and the remaining $15 \%$ in the category of "very good" ( > 90). Cycle II of the first meeting results obtained $10 \%$ of students are in the category of "less" (30-49), 20\% of the category of "enough" (50-69), 50\% in the category of "good" (70-89), and the remaining $20 \%$ in the "very good" category (>90). Whereas in the second cycle meeting 2 researchers obtained results of $0 \%$ of students in the poor category $(<29)$, 5\% of students were still in the "poor" category (30-49), 25\% of the "sufficient" category (50-69), 30\% in the "good" category (70-89), and the remaining 40\% in the "very good" category (>90). With the analysis of these data, it can be concluded that the application of PAIKEM GEMBROT can be used as an alternative learning to improve student learning outcomes.

Keywords: PAIKEM Gembrot, learning outcomes, science

@ Jurnal Basicedu Prodi PGSD FIP UPTT 2019

$\triangle$ Corresponding author :

Address :

Email

ISSN 2580-3735 (Media Cetak)

Phone 


\section{PENDAHULUAN}

Dalam Standar proses pendidikan, pembelajaran menempatkan siswa sebagai subjek yang berorientasi pada aktivitas siswa. Seperti yang dikemukakan pada Bab IV Pasal 19 Peraturan Pemerintah No.19 Tahun 2005 mengemukakan bahwa: Proses pembelajaran pada satuan pendidikan diselenggarakan secara interaktif, menyenangkan menantang, memotivasi peserta didik untuk berpartisipasi aktif serta memberikan ruang yang cukup bagi prakarsa, kreativitas dan kemandirian sesuai dengan bakat, minat dan perkembangan fisik serta psikologis peserta didik.

Dari peraturan pemerintah diatas bahwa pembelajaran tidak sekedar penyampaian pengetahuan dari guru ke siswa, akan tetapi dalam mengajar sebagai proses mengatur lingkungan yang dapat merangsang siswa untuk belajar. Dengan adanya rangsangan dari luar siswa termotivasi untuk belajar yang didorong oleh keinginan untuk memenuhi kebutuhannya, sehingga pembelajaran dapat berorientasi pada pencapaian tujuan.

Agar tujuan dari pembelajaran dapat tercapaian secara maximal, maka guru perlu menciptakan atau mencari strategi yang tepat dengan keadaan sesuai dengan minat kebutuhan siswa sehingga siswa mempunyai motivasi belajar yang tinggi. Dengan demikian, diperlukan guru yang kreatif baik dalam meyiapkan kegiatan belajar maupun dalam proses pembelajaran berlangsung dengan mengaturnya agar menjadi lebih bermakna, menarik, menyenangkan dan utuh.

Dari sana tercipta suasana pembelajaran yang kondusif, suasana pembelajaran yang menantang. dan mampu menciptakan pembelajaran yang menyenangkan. Hal ini penting. karena dalam pembelajaran guru memiliki peranan yang sangat penting dalam proses pendidikan. baik sebagai perencana, pelaksana, maupun evaluator pembelajaran. Dengan demikian kemampuan professional guru dalam menciptakan pembelajaran yang berkualitas sangat menentukan keberhasilan proses pendidikan secara keseluruhan.

Salah satu keberhasilan pendidikan dalam tataran level kelas adalah tatkala seorang guru mampu membangun motivasi belajar para siswanya yang ditandaidengan siswa ikut berpartisipasi aktif, inovatif, kreatif dan menyenangkan dalam pembelajaran. Hal ini senada dengan pernyataan yang diungkapkan Sanjaya (2010/30) bahwa siswa hanya mungkin dapat belajar dengan baik manakala ada dalam suasana yang menyenangkan, merasa aman dan bebas dari rasa takut.

Walaupun demikian, temuan peneliti dilapangan selama melakukan observasi langsung terhadap proses pembelajaran di kelas 11 SD Negeri Manggarai 09 Kecamatan Tebet Jakarta Selatan ketika proses pembelajaran masih banyak siswa yang ribut dan mengerjakan aktivitas lainnya, sehingga siswa banyak yang kurang fokus. Hal ini juga terbukti dengan adanya siswa yang bolos setiap harinya.

Dalam pembelajaran berlangsung banyak siswa yang cenderung pasif dalam pembelajaran. Keterlibatan siswa dalam proses pembelajaran hanya sebagai penerima informasi apa yang disampaikan, kegiatannya hanya sekedar menerima informasi dan mencatat apa yang ditulis guru dipapan tulis. Dari system pembelajaran seperti itu, tidak melatih siswa untuk aktif dalam proses pembelajaran. Sehingga, hasil ulangan pembelajaransains siswa, yang tuntas KKM hanya 15 orang atau $50 \%$ dari yang berjumlah 30 orang. Kemampuan siswa pada pembelajaran sains 


\section{Penerapan PAIKEM GEMBROT untuk meningkatkan hasil belajar sains di sekolah dasar-}

Mulyani Sabihi

belum berkembang secara optimal. Hal ini terlihat. Ketika siswa mengenakan soal sering bertanya. karena ketidaktahuan mereka dalam menjawab soal—soai yang diberikan.

Kondisi tesebut merupakan permasalahan yang harus segera diatasi, karena apabila hasil belajar sains dikelas II rendah maka akan mendapatkan kesulitan dalam memecahkan masalah kehidupan sehari-hari mereka. Pasalnya sains sangat erat kaitannya dengan lingkungan sekitar yang langsung berhubungan dengan kehidupan sehari-hari siswa.

Dalam KTSP IPA untuk SD/MI disebutkan bahwa Ilmu Pengetahuan Alam (IPA) berhubungan dengan cara mencari tahu tentang alam secara sistematis, sehingga IPA bukan hanya penguasaan kumpulan pengetahuan yang berupa fakta-fakta, konsep-konsep, atau prinsip-prinsip saja tetapi juga merupakan suatu proses penemuan. Pendidikan IPA diharapkan dapat menjadi wahana bagi peserta didik untuk mempelajari diri sendiri dan alam sekitar, serta prospek pengembangan lebih lanjut dalam menerapkannya di dalam kehidupan seharihari.

Proses pembelajarannya menekankan pada pemberian pengalaman langsung untuk mengembangkan kompetensi agar menjelajahi dan memahami alam sekitar secara ilmiah. Pendidikan IPA diarahkan untuk inkuin dan berbuat sehingga dapat membantu peserta didik untuk memperoleh pemahaman yang lebih mendalam tentang alam sekitar.

Berdasarkan pengertian diatas dalam menerapkan pada kehidupan sehari-hari yang disesuikan dengan dunia anak sebagai pusat lingkungan dengan secara menyeluruh yang berangkat dari hal yang bersifat kongkrit.Untuk itu - guru dituntut untuk kreatif dalam mendesain model pembelajaran yang disenangi oleh anak dan bermakna bagi siswa sehingga siswa dapat menghubungkan konsep yang dipelajarinya dengan dunia anak dalam kehidupan sehari-hari secara holistik. Dengan demikian, siswa diharapkan dengan mudah memahami materi yang diberikan.

Dalam mendesain model sesuai dengan permasalahan di atas, yaitu dengan renerapan PAIKEM Gembrot yang menekankan peserta didik baik secara ndividu maupun kelompok untuk aktif mencari, menggali dan menemukan consep serta prinsip-prinsip secara holistik dan otentik. Oleh karena itu melaksanaan memerlukan sarana dan prasarana, bahan ajar, sumber belajar, serta lembelajaran pendukung yang cukup bagi proses pembelajaran.

Prinsip holistik dan otentik sesuai dengn pengertian PAIKEM Gembrot ang merupakan gabungan anatarbidang kajianyang dalam pelaksanaanya tidak srpisah-pisah menjadi satu kesatuan dan keterpaduan. Hal ini memberikan nplikasi terhadap guru yang mengajar dikelas. Menurut Depdiknas (2006), ahwa PAIKEM Gembrot memerlukan guru yang kreatif baik dalam sgiatan/pengalaman belajar bagi siswa juga dalam memilih kompetensi dari irbagai mata pelajaran dan mengaturnya agar pembelajaran menjadi lebih jrmakna, menarik, menyenangkan dan utuh. (Ahmadi dan Amri: 2011:58).

Suasana belajar yang menyenangkan akan membuat guru mampu enyampaikan materi pembelajaran dengan baik, dipihak lain siswa akan dapat enerima materi dengan senang, sehingga apa yang disampaikan oleh guru akan bih cepat diterima siswa.

PAIKEM Gembrot merupakan model pembelajaran yang termasuk model embelajaran terpadu. Istilah PAIKEM Gembrot pada dasarnya adalah model embelajaran terpadu yang menggabungkan beberapa mata pelajaran dengan lenggunakan tema untuk mengaitkan 
beberapa mata pelajaran sehingga dapat

lemberikan pengalaman bermakna kepada siswa

Hadi Subroto (dalam Ahmadi dan Amri, 2011:16) menegaskan bahwa imbelajaran terpadu adalah pembelajaran yang diawali dengan suatu pokok ihasan atau spontan atau direncanakanan secara tema tertentu yang dikaitkan ngan konsep lain, yang dilakukan secara spontan baik dalam bidang studi atau dan dengan beragam pengalaman belajar siswa, maka pembelajaran menjadi lebih bermakna. Maka, pada umumnya PAIKEM Gembrot adalah pembelajaran ng menggunakan tema tertentu untuk mengaitkan antara beberapa isi mata lajaran dengan pengalaman kehidupan nyata sehari-hari siswa sehingga dapat memberikan pengalaman bermakana bagi siswa.

Jadi disimpulkan, PAIKEM Gembrot adalah bentuk pembelajaran yang nggunakan tema tertentu untuk mengaitkan antar isi mata pelajaran dengan igaitkan kehidupan sehari-hari siswa dan menjadikan proses pembelajaran yang efektif dan menarik yang melibatkan siswa secara partisipatif, aktif, inovatif, itif, gembira dan berbobot sehingga pembelajaran menjadi lebih bermakna.

PAIKEM Gembrot, sebagai model pembelajaran memiliki arti penting dalam nbangun peserta didik antara lain. Pertama, PAIKEM Gembrot lebih menekankan proses pembelajarannya jan memperoleh pengalaman langsung dan terlatih untuk dapat menemukan liri berbagai pengetahuan yang dipelajarinnya yang menuntut pada partisipasi a secara aktif. Sehingga melalui pengalaman langsung siswa memahami konsep-konsep yang mereka pelajari dan menggabungkan konsep-konsep lain telah dipahaminya semakin baik dan meningkat.

\section{Hasil Belajar}

Keberhasilan siswa dapat dilihat setelah ia mengalami proses belajar. Oleh na itu hasil belajar siswa tergantung pada proses belajar agar terjadi bahan tingkah laku yang texjadi pada diri siswa. Ciri teijadinya perubahan :ah laku pada diri siswa ditunjukkan oleh sejumlah kemampuan memahami nenguasai materi pelajaran yang disampaikan dalam proses belajar mengajar. Hal ini sesuai dengan pendapat Sudjana (2010:22), bahwa hasil belajar adalah :mampuankemampuan yang dimiliki siswa setelah ia menerima pengalaman belajar.

Dalam sistem pendidikan nasional, pengklasifikasian hasil belajar yang idopsi adalah klasifikasi yang dikemukakan oleh Blom dalam Sudjana ) 10:22), secara garis besar membagi hasil belajar menjadi tiga ranah, yaitu lah kognitif, afektif dan psikomotor. Menurut Sagala (2007:12) bahwa orang $\lg$ belajar dari ketiga ranah ini akan makin baik.

Agar tercapainya tujuan pendidikan dan memenuhi pendidikan IPA, pendekatan yang digunakan dalam proses belajar mengajar IPA adalah (Pendekatan lingkungan). Pendekatan keterampilan proses Pendekatan inquiry (penyelididkan) I. Pendekatan terpadu (terutama di SD).

Salah satu pendekatan yang dilakukan dalam proses belajar mengajar IPA sains yaitu pendekatan terpadu. Seperti yang dikatakan oleh Fogarty (dalam atowa, 2010 :68) suatu proses belajar mengajar dalam model pembelajaran du memadukan beberapa konsep IPA yang terkait menjadi satu paket )elajaran sehingggapemisahan anataar konsep tidak begitu jelas. iedangkan menurut Ahmadi dan Amri (2011:16) PAIKEM Gembrot pakan model pembelajaran yang menggunakan tema tertentu secara terpadu : mengitkan antara isi beberapa mata pelajaran dengan pengalaman kehidupan nyata sehari-hari siswa sehingga dapat memberikan pengalaman yang rmakna bagi siswa. 
Samatowa (2011:68) menegesakan Karakteristik siswa SD yang suka bermain, memiliki rasa ingin tahu yang besar, dan mudah terpengaruh oleh lingkungan perlu tercipta lingkungan pembelajaran yang menyenangkan, anatara lain prinsip belajar sambil bermain sambil belajar. Melalui program bermain sambil belajar dari pengalaman bermainnya, sehingga secara langsung muncul kreativitas dari pengalaman bermain.

IPA merupakan hasil kegiatan manusia berupa pengetahuan, gagasan, konsep yang terorganisasi tentang alam sekitar dari pengujian pengalaman melalui serangkai ses ilmiah seperti penyelididkan, penyususnan dan pengujian gagasan. Oleh :na itu, dalam pembelajaran siswa membangun pengetahuan berdasarkan gamatan, penyusunan gagasan melalui suatu percobaan sangatlah penting. im mengembangkannya pembelajaran terpadu siswa dilibatkan dalam atan langsung pada objek nyata, karena akan membantu siswa dalam berpikir ilui pengalaman belajarnya.

Jadi, sains atau IPA sangat berhubungan erat dengan PAIKEM Gembrot na salah pendekatannya IPA yaitu dengan pendekatan terpadu dan kteristik dari PAIKEM Gembrot adalah menggabungkan beberapa tema ra terpadu. Yang artinya sains atau IPA dengan PAIKEM Gembrot sama dengan menggunakan pendekatan dan karakteristik terpadu dengan penerapan belajar sambil melakukan sesuatu dengan mengadopsi belajar PAKEM pembelajaran aktif, kreatif, efektif dan menyenangkan yang artinya dalam proses belajarnya bermain sambil belajar dari pengalaman bermainnya.

Oleh karena itu, hasil belajar sains dengan penerapan PAIKEM Gembrot ng dimaksud adalah kemampuan yang dimiliki siswa setelah menerima ngalaman belajar melalui penerapan PAIKEM
Gembrot yang dilihat pada ranah gnitif dari hasil nilai evaluasi siswa setelah penerapan PAIKEM Gembrot dan ratah afektif dan psikomotor dilihat pada saat melakukan keija kelompok yang imati oleh obsever pada tema lingkungan alam

\section{METODE}

Metode yang digunakan penelitian ini yaitu penelitian tindakan kelas (action research). Tempat penelitian akan dilaksanakan di kelas II SD Negeri Manggarai 09 kecamatan Tebet Jakarta Selatan. Subjek penelitian ini adalah siswa kelas II SD Negeri Manggarai 09 camatan Tebet Jakarta Selatan. Jumlah siswa kelas II SD Negeri Manggarai 09 camatan Tebet Jakarta Selatan sebanyak 20 orang siswa yang terdiri dari 9 wa laki-laki dan 11 siswa perempuan.

Kegiatan yang dilakukan dalam perencanaan tindakan yaitu terlebih iahulu peneliti mengkaji teori-teori yang mendukung seperti menelaah uirikulum KTSP untuk SD/MI, menelah materi yang kan diajarkan yang kemudian menyusun perangkat pembelajaran seperti RPP, LKS dan media pembelajaran lalu menyusun instrumen penelitian yang selanjutnya lengkonsultasikan instrumen penelitian dan RPP yang telah dibuat kepada dosen pembimbing agar instrumen dan RPP dalam penelitian sesuai dengan yang diharapkan serta mendiskusikan dengan rekan guru SD Negeri Manggarai 09 Pagi Kecamatan Tebet Jakarta Selatan yang akan diminta observer.

Siklus I ini terdiri dari dua kali pertemuan yang dialokasikan selama 140 menit atau 4 x 35 menit. Peneliti melaksanakan pembelajararan bertema lingkungan alam dengan penerapan PAIKEM Gembrot, dengan langkahlangkah yang ditempuh sesuai dengan RPP yang mengacu pada sintaks PAIKEM Gembrot. Siklus I ini materi lebih di tekankan pada posisi matahari dengan fase-fase pembelajaran sebagi berikut. 


\section{Penerapan PAIKEM GEMBROT untuk meningkatkan hasil belajar sains di sekolah dasar-}

Mulyani Sabihi

Fase pendahuluan dengan memotivasi siswa dengan nyanyian "matahari", fase presentasi materi siswa melakuakan demontrasi menganai perbedaan posisi matahari dari pagi hingga senja, fase membimbing pelatihan siswa dibagi kelompok dengan melakukan kerjasama mengurutkan perubahan posisi matahrari dari pagi hingga senja hari, fase menelaah pemahaman siswa mempersentasikan hasil yang telah dikeijakannya lalu pada tahap akhir menyimpulkan materi.

Dalam tahap ini, peneliti melakukn kemitraan dengan du orang observer antuk mengamati aktivitas yang teijadi selama proses pembelajaran jerlangsung beerdasarkan temuan-temuan oleh guru maupun observer yang .eijadi dilapangan. Dari hasil penemuan tersebut dapat dijadikan acuan untuk nengamati kesesuaian penerapan PAIKEM Gembrot dengan hasil yang diinginkan sehingga dapat dijadikan referensi untuk penyususnan siklus selanjutnya. Selain itu sikap dan prilaku siswa diamati dengan aspek-aspek tertentu pada pengamatan afektif dan psikomotor siswa dan juga menganalisis hasil belajar siswa untuk mengatuhui pemahaman siswa terhadap pembelajaran setelah diberi tindakan.

Pada tahap refleksi peneliti melakukan diskusi dengan mitra berdasarkan hasil pengamatannya dan evaluasi berkaitan dalam penerapan PAIKEM Gembrotdalam kegiatan belajar mengajar dan membuat rencana perbaikanperbaikan terhadap kekurangan-kekurangan yang di temukan setelah melakukan diskusi dengan mitra peneliti. Lalu melaksanakan pengolahan data yang diperoleh setelah penelitian selesai di laksanakan dan menyimpulkan hasil refleksi tindakan, yang akan digunakan sebagai tindakan selanjutnya. Tindakan akan dilanjutkan sampai memenuhi indikator keberhasilan, jika $82 \%$ nilai evaluasi siswa dalam tema Lingkungan Alam sudah mencapai KKM.
Seperti halnya siklus I, tahap refleksi peneliti pada siklus II ini melakukan diskusi dengan mitra berdasarkan hasil pengamatannya dan evaluasi berkaitan dalam penerapan PAIKEM Gembrot dalam kegiatan belajar mengajar dan membuat rencana perbaikanperbaikan terhadap kekurangan-kekurangan yang di temukan setelah melakukan diskusi dengan mitra peneliti. Lalu melaksanakan pengolahan data yang diperoleh setelah penelitian selesai di laksanakan dan menyimpulkan hasil refleksi tindakan, yang akan digunakan sebagai tindakan selanjumya.Tindakan akan dilanjutkan sampai memenuhi indikator keberhasilan. jika $82 \%$ nilai evaluasi siswa dalam tema Lingkungan Alam sudah mencapai KKM. Berdasarkan alur model Kemmis dan Taggart, hasil dari refleksi I untuk mperbaiki pelaksanaan pada tindakan pada siklus selanjutnya. Apabila siklus iga ini belum mencapai indikator keberhasUan yang diharapkan maka uijutkan pada siklus berikutnya dan dan apabila telah memenuhi indikator keberhasilan penelitian Tindakan akan dilanjutkan sampai memenuhi indicator keberhasilan, jika $82 \%$ nilai evaluasi siswa dalam tema Lingkungan Alam sudah ticapai KKM.

Teknik pengumpuland data merupakan cara-cara yang itempuh untuk himpun data yang diambil pada saat penelitian.

Data hasil belajar kognitif diperoleh dari hasil evaluasi diakhir pembelajaran ada setiap pertemuan yang diberi skor setiap jumlah yang benar. Menghitung pencapaian nilai siswa setiap siklus, yaitu dengan mengggunakan rumus:

Nilai Siswa $=\underline{\text { skor yang diperoleh } \times 100}$

Skor maksimum 
2150 Penerapan PAIKEM GEMBROT untuk meningkatkan hasil belajar sains di sekolah dasar-

Mulyani Sabihi

Hasil presentasi ketuntasan belajar diinterpretasikan berdasarkan tabel dibawah ini:

Tabel 1 Standarisasi Penguasaan

\begin{tabular}{|l|l|l|}
\hline Angka 100 & Angka 10 & Katagori \\
\hline $80-100$ & $8,0-10$ & Baik sekali \\
\hline $66-79$ & $6,6-7,9$ & Baik \\
\hline $56-65$ & $5,6-6,5$ & Cukup \\
\hline $40-55$ & $4,0-5,5$ & Kurang \\
\hline $0-39$ & $0-3,9$ & Gagal \\
\hline
\end{tabular}

(Sumber: Arikunto, 2011: 234)

Data hasil observasi ranah afektif dan psikomotor berupa ratting score untuk setiap katagori di jumlahkan. Skor yang diperoleh siswa sesuai Tabel dan ranah afektif dan psikomotor kemudian dihitung presentasinya

Tabel 2 Persentase Aspek Afektif

\begin{tabular}{|c|c|}
\hline Persentase & Katagori \\
\hline $80 \%$ atau lebih & Sangat baik \\
\hline $60 \%-79 \%$ & Baik \\
\hline $40 \%-59 \%$ & Cukup \\
\hline $21 \%-39 \%$ & Rendah \\
\hline $0-20 \%$ & Rendah sekali \\
\hline (Saadah Ridwan, 2000:13 dalam Dewi, M.R,
\end{tabular}

\section{Tabel 3}

Klasifikasi Persentase Aspek Psikomotor

\begin{tabular}{|l|c|}
\hline Persentase & Katagori \\
\hline $90 \%$ atau lebih & Sangat Terampil \\
\hline $75 \%-89 \%$ & Terampil \\
\hline $55 \%-74 \%$ & Cukup Terampil \\
\hline $31 \%-54 \%$ & Kurang Terampil \\
\hline $0-30 \%$ & Sangat Kurang Terampil \\
\hline
\end{tabular}

(Luhut pangabean, 1989:32 dalam Dewi, M.R, 2012:40)

Selanjutnya, hasil belajar ranah afektif dan psikomotor, hasil presentase rata- digambarkan pada grafik.

Langkah - langkah dilakukan untuk menghitung persentase keterlaksanaan ibelajaran yaitu sebagai berikut:
Menghitung jumlah jawaban "YA" yang observer isi pada lembar observasi keterlaksanaan model pembelajaran.

Menghitumg persentase keterlaksanaan model pembelajaran PAIKEM Gembrot pada setiap fase guru dan siswa, dengan persamaan sebagai berikut:

Tabel 4. Keterlaksanaan Aktivitas Guru dan Siswa

\begin{tabular}{|l|l|}
\hline Persentase & Katagori \\
\hline $87.60 \%-100 \%$ & Sangat baik \\
\hline $62.60 \%-87.50 \%$ & Baik \\
\hline $37.60 \%-62.50 \%$ & Cukup \\
\hline $25.00 \%-37.50 \%$ & Kurang \\
\hline $0-24.90 \%$ & Sangat Kurang \\
\hline
\end{tabular}

\section{HASIL DAN PEMBAHASAN}

Studi pendahuluan merupakan langkah awal dari pelaksanaan penelitian. la bagian ini penulis uraikan proses studi pendahuluan tersebut. Seluruh gkaian kcgiatan penelitian ini dilaksanakan dua siklus empat pertemuan. jiatan penelitian ini diawali dengan menemukan permasaiahan awal yang lami siswa, sehingga dengan demikian penulis memiliki suatu alternatif untuk igatasi masalah tersebut.

Berdasarkan hasil wawancara dengan guru kelas II menyatakan bahwa lampuan kreatif siswa kelas II masih kurang karena beberapa faktor yaitu (1) pentingnya motivasi siswa untuk belajar. (2) kejenuhan siswa dalam pembelajaran I hanya mencatat dan mendengarkan guru. (3) kurangnya antusias siswa $m$ pembelajaran Sains pada umumn>a dan maien Lingkungan Alam pada susnya, (4) sulitnya siswa untuk laageabai^un imajinasi dan lain gainya.

Berdasarkan hasil observasi awal. penulis melihat secara langsung bahwa kemampuan kreatif siswa masih kurang. Pada proses pembelajaran sias siswa sangat kurang pada materi Lingknngan Alam. Model pembelajaran ; digunakan guru kurang bervariasi, menjadikan siswa merasa bosan 


\section{Penerapan PAIKEM GEMBROT untuk meningkatkan hasil belajar sains di sekolah dasar- Mulyani Sabihi}

dan jenuh terhadap pembelajaran Sains yang selama ini hanya tanya duduk mendengarkan guru menjelaskan materi sambil mencatat apa yang dituliskan guru tulis.

Berdasarkan hasil wawancara dan observasi awal di atas, penulis dapat menyimpulkan bahwa diperlukan suatu alternatif pembelajaran untuk diterapkan lam pembelajaran Sains, agar dapat meningkatkan kemampuan kreatif siswa dan materi Lingkungan Alam. Pembelajaran dengan penerapan metodc PAIKEM Gembrot serta lembar untuk membuat metode PAIKEM Gembrot.

Pada bagian ini akan dideskripsikan hasil penelitian pada siklus I pertemuan 1 yang dimulai dari perencanaan (Plan). Pelaksanaan tindakan (Action), pengamatan (Observasi) yang dibetawi oleh observer dan ikhir melakukan Refleksi (Reflection).

Dal am tahap perencanaan pada siklus I pertemuan 1 peneliti menyusun apa hal, antara lain adalah:isil analisis kurikulum untuk mengetahui kompetensi dasar yang diterapkan dalam RPP berkaitan dengan konsep Lingkungan Alam. embuat RPP tentang Lingkungan Alam termasuk di dalamnya menyusun igkah kegiatan pembelajaranyang melibatkan metode PAIKEM Gembrot. jnyiapkan media pembelajaran berupa gambar Lingkungan Alam dan nyiapkan alat dan bahan percobaan sederhana tentang proses teijadinya an agar siswa lebih konkrit dalam menerima materi pembelajaran. mbuat instrumen penelitian berupa test untuk mengukur kemampuan pikir lancar siswa sebanyak 5 soal beserta rubrik penilaiannya, lembar ervasi guru dan aktivitas siswa untuk mengetahui tanggapan mengenai smbelajaran dengan penerapan metode PAIKEM Gembrot serta lembar untuk lembuat metode PAIKEM Gembrot.

Pelaksanaan siklus I pertemuan 1 dilaksanakan hari Selasa, tanggal 26 uari 2019 pukul 07.00-09.20 WIB. Dalam pelaksanaannya peneliti npingi observer yang menilai keseluruhan pembelajaran. Dalam proses )elajaran peneliti melaksanakan langkah-langkah pembelajaran dalam RPP cana pelaksanaan pembelajaran) yang telah dirancang sebelumnya dengan :apan model PAIKEM Gembrot.

Pada bagian ini penulis akan mendeskripsikan hasil observasi pelaksanaan > ke-1 pertemuan 1. Dalam siklus ini peneliti menemukan beberapa kendala, masih ada beberapa siswa yang tidak fokus ketika pembelajaran dan masih >a bingung ketika diberi tugas. Namun, setelah guru memberikan motivasi ienjelasan kepada siswa tertentu, kegiatan pembelajaran kembali tertib dan an sesuai dengan RPP.

Di bawah ini akan diuraikan hasil observasi guru dan siswa pada siklus 1 nuan 1 dengan menerapkan model PAIKEM Gembrot materi Lingkungan siswa kelas II SD Negeri Manggarai 09 Kecamatan Tebet Jakarta Selatan. observasi siswa adalah sebagai berikut:

Tabel 5

\section{Hasil Observasi Aktivitas Siswa Pada Siklus I} Pertemuan 1

\begin{tabular}{|c|c|c|c|c|}
\hline Aspek & Kate & bri Penil & aian & Jumlah \\
\hline Dinilai & baik & cukup & kurang & \\
\hline $\mid \begin{array}{lr}\text { Aktivitas } & \text { siswa } \\
\text { dalam } & \text { bertanya } \\
\text { jawab } & \end{array}$ & & & & 3 \\
\hline $\begin{array}{ll}\text { Aktivitas } & \text { siswa } \\
\text { dalam } & \\
\text { memecahkan } \\
\text { masalah } \\
\text { diajarkan }\end{array}$ & & & & 3 \\
\hline $\begin{array}{l}\text { Antusias siswa } \\
\text { dalam } \\
\text { menyimak } \\
\text { penjelasan guru }\end{array}$ & & V & & 2 \\
\hline $\begin{array}{lr}\text { Sikap r siswa } \\
\text { dalam } & \text { mengikuti } \\
\text { proses } & \\
\text { pembelajaran }\end{array}$ & & & & 2 \\
\hline $\begin{array}{l}\text { Aktivitas siswa } \\
\text { dalam } \\
\text { mengajukan } \\
\text { gagasan dalam }\end{array}$ & & & & 3 \\
\hline
\end{tabular}




\begin{tabular}{|l|l|l|l|l|}
\hline Aspek yang Kategori Penilaian & Jumlah \\
Dinilai & baik & cukup & kurang & \\
\hline pembuatan & & & & \\
Metode & & & & \\
PAIKEM & & & & \\
Gembrot & & & & \\
\hline Presentase & & $65 \%$ \\
\hline
\end{tabular}

Berdasarkan tabel di atas, dapat dilihat aktivitas siswa dalam kegiatan pelajaran pada siklus I pertemuan 1 cukup dengan presentase 65\%. Siswa cukup baik dalam memecahkan masalah yang diajarkan, menyimak asan guru dan bersikap dalam mengikuti proses pembelajaran. Siswa juga baik dalam bertanya jawab dan mengajukan gagasan dalam pembuatan e PAIKEM Gembrot. Dengan demikian hasil diatas membuktikan bahwa ruhan pembelajaran sudah beijalan cukup baik walaupun ada beberapa hal tarus lebih diperbaiki.

Pada kegiatan pembelajaran siklus 1 pertemuan 1 tidak hanya aktivitas yang diamati, melainkan aktivitas guru pun diamati oleh observer. Di ini merupakan hasil observasi guru.

Secara keseluruhan jika dilihat dan presentase hasil tabel di atas, •capaian RPP pada siklus I pertemuan 1 sudah dapat dikalakan baik namun ipat catatan perbaikan kedepannya yang diberikan observer untuk peneliti.

Berdasarkan hasil observasi di atas, peneliti melakukan refleksi dengan rver untuk memperbaiki siklus berikutnya yaitu lebih memperhatikan ukuran a gambar yang digunakan.

Setelah melakukan pelaksanaan proses pembelajaran Sains, peneliti kukan analisis, evaluasi dan penilaian terhadap hasil pembelajaran dengan ie PAIKEM Gembrot dan tes tentang Lingkungan Alam. Peneliti elompokkan data tersebut diantaranya adalah: (1) hasil pre test siswa, (2) post tes siswa, (3) hasil observasi/penilaian aktivitas siswa selama proses elajaran, (4) hasil observasi/penilaian aktivitas guru selama proses slajaran. Peneliti membuat rubrik penilaian berdasarkan hasil yang yang $\mathbf{I}$ Berikut adalah analisis hasil pembelajaran siswa pada siklus I

Tabel 6

Kategori Nilai Kemampuan Originality Siswa Kelas II Siklus I Pertemuan 1

\begin{tabular}{|l|r|c|}
\hline \multicolumn{1}{|c|}{ Kategori } & $\begin{array}{l}\text { Jumlah } \\
\text { Siswa }\end{array}$ & Presentase \\
\hline Baik Sekali (> 90) & 1 & $5 \%$ \\
\hline Baik (70-89) & 10 & $50 \%$ \\
\hline Cukup (50-69) & 6 & $30 \%$ \\
\hline Kurang (30-49) & 3 & $15 \%$ \\
\hline Buruk (<29) & 0 & $0 \%$ \\
\hline
\end{tabular}

Tabel 7

Kategori Nilai Kemampuan Fluency Siswa Siklus I Pertemuan 1

\begin{tabular}{|l|l|c|}
\hline \multicolumn{1}{|c|}{ Kategori } & $\begin{array}{l}\text { Jumlah } \\
\text { Siswa }\end{array}$ & Presentase \\
\hline Baik Sekali (> 90) & 0 & $0 \%$ \\
\hline Baik (70-89) & 7 & $35 \%$ \\
\hline Cukup (50-69) & 8 & $40 \%$ \\
\hline Kurang (30-49) & 4 & $20 \%$ \\
\hline Buruk (<29) & I & $5 \%$ \\
\hline
\end{tabular}

Setelah dilaksanakan tindakan yang disertai dengan observasi dan evaluasi 1 belajar siswa, selanjutnya diadakan refleksi terhadap hal-hal yang telah idi. Catatan-catatan dan nilai observasi itu dimanfaatkan untuk dijadikan )man dalam melaksanakan tindakan berikutnya.

Dalam pelaksanaan siklus I pertemuan 1, peneliti melihat beberapa lala yang harus diperbaiki untuk siklus berikutnya, yaitu: Siswa terlihat kesulitan dalam menuangkan ide ketika mengisi soal. Hal ini liduga karena siswa kurang memahami materi. Oleh karena itu peneliti akan nenjelaskan kembali materi kepada siswa sebelum kegiatan pembelajaran tidak ada siklus berikutnya. 
Siswa tidak memahami maksud soal yang diberikan guru sehingga kesulitan alam menjawabnya. Hal ini diduga karena siswa kurang memperhatikan guru ketika menjelaskan materi atau bisa juga kalimat yang digunakan sehingga soal sulit dimengerti. Oleh karena itu pada siklus berikutnya peneliti akan mengoreksi pemilihan kata dalam pembuatan soal dan lebih mengkondisikan kelas ketika pembelajaran berlangsung agar perhatian siswa dapat fokus kepada guru.

Manajemen waktu dalam membuat penerapan metode PAIKEM Gembrot harus lebih ditegaskan kepada siswa agar siswa lebih tertib dalam penerapan net ode PAIKEM Gembrot.

Pada bagian ini akan dideskripsikan hasil penelitian pada siklus I 2 yang dimulai dari melakukan perencanaan (Plan), Pelaksanaan (Action), pengamatan (Observation) yang dilakukan oleh observer dan diakhiri Refleksi (Reflection). Memulai siklus I pertemuan 2, peneliti melaksanakan tahap berisi kegiatan melatih siswa dengan metode PAIKEM Gembrot 1 kali pertemuan dengan tema Lingkungan Alam. Perencanaan Pada Siklus I Pertemuan 2 peneliti menyusun lain adalah:

Menyiapkan kurikulum untuk mengetahui kompetensi dasar yang diterapkan berkaitan dengan konsep Lingkungan Alam. tentang Lingkungan Alam termasuk di dalamnya menyusun pembelajaran yang menggunakan metode PAIKEM Gembrot.

Menyiapkan media pembelajaran berupa alatr peraga Ilmu Pengetahuan Alam dan menyiapkan alat dan bahan percobaan sederhana untuk mengetahui proses terjadinva hujan agar siswa lebih konkrit dalam menerima pelajaran. Membuat instrumen penelitian berupa test kemampuan berpikir lancar siswa sebanyak 5 soal beserta rubrik penilaian. Dan lembar observasi guru dan aktivitas siswa untuk mengenai pembelajaran dengan penerapan metode $\mathrm{P}$ AIKEM Gembrot.

Deskripsi Pelaksanaan Pada Siklus I Pertemuan 2 dimulai hari Selasa, tanggal 5 maret 2019 pukul 07.00-09.20 WIB. Dalam pelaksanaan peneliti didampingi observer yang menilai keseluruhan pembelajaran. Dalam proses pembelajaran peneliti melaksanakan langkahlangkah RPP yang dirancang.

Setelah melakukan pelaksanaan proses pembelajaran I P.A peneliti akukan analisis, evaluasi dan penilaian terhadap hasil pembelajaran membuat roudmap dan tes tentang Lingkungan Alam. Peneliti mengelompokkan data diinput diantaranya adalah: (1) hasil pre test siswa, (2) hasil post tes siswa. (3) I observasi/penilaian aktivitas siswa selama proses pembelajaran, (4) hasil revisi/penilaian aktivitas guru selama proses pembelajaran.

Tabel 8

Kategori Nilai Kemampuan Fluency Siswa Siklus I Pertemuan 2

\begin{tabular}{|l|l|c|}
\hline Kategori & $\begin{array}{l}\text { Jumlah } \\
\text { Siswa }\end{array}$ & Presentase \\
\hline Cukup (50-69) & 6 & $30 \%$ \\
\hline Kurang (30-49) & 4 & $20 \%$ \\
\hline Buruk (<29) & 1 & $5 \%$ \\
\hline
\end{tabular}

Setelah dilaksanakan tindakan yang disertai dengan observasi dan evaluasi I belajar siswa, selanjutnya diadakan refleksi terhadap hal-hal yang telah di. Catatan-catatan dan nilai observasi itu dimanfaatkan untuk dijadikan dalam melaksanakan tindakan berikutnya. Dalam pelaksanaan siklus I pertemuan 2, peneliti melihat beberapa ala yang harus diperbaiki untuk siklus berikutnya, yaitu: Siswa terlihat kesulitan dalam mengisi soal. Oleh karena itu peneliti akan nenjelaskan kembali materi kepada siswa sebelum kegiatan pembelajaran jada siklus berikutnya. Siswa tidak memahami maksud soal yang 


\section{Penerapan PAIKEM GEMBROT untuk meningkatkan hasil belajar sains di sekolah dasar- Mulyani Sabihi}

diberikan guru sehingga kesulitan lalam menjawabnya. Hal ini diduga karena siswa kurang memperhatikan ;uru ketika menjelaskan materi atau bisa juga kalimat yang digunakan dalam oal sulit dimengerti. Oleh karena itu pada siklus berikutnya peneliti akan lengoreksi pemilihan kata dalam pembuatan soal dan lebih mengkondisikan kelas ketika pembelajaran kepada guru.

Dalam tahap perencanaan pada siklus didasarkan pads hasfl rerieks: pada siklus I pertemuan 2. Pada dasarnya perencanaan pada siklus II pertemuan 1 tidak jauh beda dengan siklus I pertemuan 2, perencanaan tersebut sebagai berikut: Hasil analisis kurikulum untuk mengetahui kompetensi dasar yang akan diterapkan di dalam RPP.

Membuat perbaikan dalam penyusunan RPP tentang kegiatan manusia yang mempengaruhi Lingkungan Alam termasuk di dalamnya menyusun langkah kegiatan pembelajaran dengan menerapkan metode PAIKEM Gembrot. Peneliti menyiapkan media pembelajaran berupa gambar yang ukurannya lebih besar dan lebih jelas terlihat mengenai kegiatan manusia yang mempengaruhi Lingkungan Alam.

Pelaksanaan siklus II pertemuan 1 Maret 2019 pukul 07.00-09.20 WIB. Dalam

lpingi observer yang menilai keseluruhan ibelajaran peneliti melaksanakan langkah- lcana pelaksanaan pembelajaran) yang telah

penerapan metode PAIKEM Gembrot. Berdasarkan hasil refleksi pada siklus I pertemuan berupa tindakan dalam pelaksanaan siklus yang diberikan latihan dalam penerapan metode PAIKEM pelajaran dimulai agar siswa lebih bisa menuangkan ide nya dalam pembuatannya, peneliti lebih dalam maksud dan menjawab dengan lebih lancar.

Pada bagian ini penulis akan mendeskripsikan hasil pelaksanaan siklus II 1 .
Dalam siklus ini peneliti tidak menemukan kendala yang berarti. besar siswa yang cukup fokus ketika pembelajaran berlangsung. Ketika siswa dapat menyelesaikannya dengan baik. Secara keseluruhan kegiatan kembali tertib dan beijalan sesuai dengan RPP. Membuat instrumen penelitian berupa test untuk mengukur kemampuan berpikir lancar siswa sebanyak 5 soal beserta rubrik penilaiannya, lembar observasi.

Tabel 9

Kategori Nilai Kemampuan Fluency Siswa Siklus I Pertemuan 2

\begin{tabular}{|l|c|c|}
\hline Kategori & $\begin{array}{l}\text { Jumlah } \\
\text { Siswa }\end{array}$ & Presentase \\
\hline Baik (7U-89) & 10 & $\mathbf{5 0 \%}$ \\
\hline Cukup (50-69) & 4 & $\mathbf{2 0 \%}$ \\
\hline Kurang (30-49) & 2 & $10 \%$ \\
\hline Buruk (<29) & 0 & $0 \%$ \\
\hline
\end{tabular}

Berdasarkan hasil diskusi dengan observer setelah temuan 1 selesai dilaksanakan, secara umum pembelajaran ijalan dengan baik karena pada kegiatan tanya jawab yang sudah mulai merata, semua siswa terlihat aktif dan saSag memberikan apat ketika guru mengajukan pertanyaan. Walaupun belum bisa fokus dalam kegiatan pembelajaran karena sibuk operasikan telepon genggam milik temannya. Setelah kegiatan pembelajaran selesai, peneliti mengolah data, observasi »u dan guru serta merefleksi keterlaksanaan pembelajaran. Hasil yang didapat iian di analisis sejauhmana kemampuan kreatif yang di dapat oleh siswa ip materi yang diberikan melalui penerapan metode PAIKEM Gembrot. keseluruhan menunjukkan bahwa pembelajaran berjalan lancar dengan siasan siswa ketika ditugaskan mengisi soal, lain halnya dengan siklus I man 2 yang masih terdapat beberapa anak yang bingung dalam mengisi soal. Pada siklus II pertemuan 1 ini hampir setab aw muuftm pdajmm dengan antusias. Namun, ada beberapa kendala 


\section{Penerapan PAIKEM GEMBROT untuk meningkatkan hasil belajar sains di sekolah dasar-}

Mulyani Sabihi

jadi pertimbangan peneliti atau guru merencanakan karena ada satu siswa yang merasa kurang mampu merasa jenuh ketika mengisi soal.

Pada akhir siklus II pertemuan 1 peneliti dengan diperoleh berupa peningkatan kemampuan kreatif menggunakan metode PAIKEM Gembrot, oleh karena itu peneliti di siklus II pertemuan 1 . Pada bagian ini akan dideskripsikan hasil luan 2 yang dimulai dari melakukan perencanaan can (Action), pengamatan (Observation) yang dilaknkan ir melakukan Refleksi (Reflection).

Dalam tahap perencanaan pada siklus didasarkan pada hasil rdieks II pertemuan 1. Pada dasarnya perencanaan pada siklus II pertemuan 2 jauh beda dengan siklus II pertemuan 1, perencanaan tersebut sebagai hasil analisis kurikulum untuk mengetahui kompetensi dasar yang akan pkan di dalam RPP. Menggunakan dalam membuat soal agar siswa lebih dapat menjawab dengan lebih lancar.

Dalam siklus ini peneliti sudah merasa siswa yang cukup fokus ketika siswa-menjawab sidalam kegiatannya pembelajaran kembali tertib dan berjalan. Di bawah ini akan diuraikan hasil observasi pertemuan di silus 2 dengan menerapkan metode PAIKEM siswa kelas II SD Negeri Manggarai 09 Pagi. Hasil observasi siswa adalah sebagai berikut:

Tabel 10

Hasil Observasi Aktivitas Siswa

\begin{tabular}{|l|l|l|l|l|r|}
\hline No & $\begin{array}{l}\text { Aspek yang } \\
\text { Dinilai }\end{array}$ & \multicolumn{3}{|c|}{ Kategori Penilaia } & \\
\hline 1 & $\begin{array}{l}\text { Aktivitas siswa } \\
\text { dalam bertanya } \\
\text { jawab }\end{array}$ & $\begin{array}{l}\text { cuku } \\
\text { p }\end{array}$ & $\begin{array}{l}\text { Kura } \\
\text { ng }\end{array}$ & $\begin{array}{l}\text { Jumla } \\
\text { h }\end{array}$ \\
\hline 2 & $\begin{array}{l}\text { Aktivitas siswa } \\
\text { dalam } \\
\text { memecahkan } \\
\text { masalah yang } \\
\text { diajarkan }\end{array}$ & & 4 \\
\hline 3 & $\begin{array}{l}\text { Antusias siswa } \\
\text { dalam } \\
\text { menyimak } \\
\text { penjelasan guru }\end{array}$ & & & \\
\hline
\end{tabular}

\section{Tabel 11}

Nilai Kemampuan Originality Siswa

\begin{tabular}{|l|c|}
\hline \multicolumn{1}{|c|}{ Kategori } & $\begin{array}{l}\text { Jumlah Sisa } \\
\text { Presentase }\end{array}$ \\
\hline Baik Sekali (>90) & $4 \mathbf{2 0 \%}$ \\
\hline Baik (70-89) & $12 \mathbf{6 0 \%}$ \\
\hline Cukup (50-69) & $4 \mathbf{2 0 \%}$ \\
\hline Kurang (30-49) & 0 0\% \\
\hline Buruk (<29) & 0 0\% \\
\hline
\end{tabular}
baik dalam memecahkan ;lasan guru dan bersikap dalam mengikun baik dalam bertanya jawab dan membuktikan bahwa keseluruhan kegiatan pun terdapat sedikit catatan yang harus lebih diperbaiki. Pada kegiatan pembelajaran siklus II pertemuan 2 diamati oleh observer. Dapat dilihat ini merupakan hasil observasi guru. Secara keseluruhan jika dilihat dari rangkaian RPP pada siklus II pertemuan 2 sudah baik.

Setelah melakukan pelaksanaan proses can analisis, evaluasi dan penilaian terhadap hasil belajar. Peneliti mengelompokkan data tersebut 1) hasil post tes siswa, (2) hasil observasi aktivitas pembelajaran, (3) hasil observasi/penilaian aktifitas dalam proses pembelajaran. Peneliti membuat rubrik penilaian berdasarkan . Berikut adalah analisis hasil pembelajran siklus 2 pembelajaran 2 . 


\section{Penerapan PAIKEM GEMBROT untuk meningkatkan hasil belajar sains di sekolah dasar- Mulyani Sabihi}

Berdasarkan hasil diskusi dengan observer setelah pembelajaran selesai dilaksanakan, secara umum pembelajaran dapat berjalan_dengan baik karena pada kegiatan tanya jawab dan diskusi kelompok. Siswa sudah mulai merata, semua siswa terlihat aktif dan saling memberikan ketika guru mengajukan pertanyaan. Walaupun masih terdapat siswa belum bisa fokus dalam kegiatan pembelajaran karena ada beberapa siswa yang memerlukan pengayaan khusus. Setelah kegiatan pembelajaran selesai, peneliti menganalisis data dari assessment observasi siswa dan guru serta merefleksi keterlaksanaan pembelajaran. Hasil yang didapat dan didian di analisis sejauhmana kemampuan kreatif yang di dapat oleh siswa materi yang diberikan melalui penerapan metode PAIKEM Gembrot. keseluruhan menunjukkan bahwa pembelajaran beijalan lancar dengan iasan siswa ketika ditugaskan mengisi soal, lain halnya dengan siklus II yang masih terdapat beberapa anak yang bingung dalam mengisi Pada siklus Ii pertemuan 2 ini hampir seluruh siswa merespon pengisian soal antusias. Namun, ada beberapa kendala yang teijadi untuk bahan gan peneliti atau guru merencanakan tindakan pembelajaran berikutnya ada satu siswa yang merasa kurang mampu untuk menggambar sehingga jenuh ketika mengisi soal.

Pada akhir siklus II pertemuan 2 peneliti sudah merasa puas dengan hasil diperoleh berupa peningkatan kemampuan kreatif siswa melalui penerapan PAIKEM Gembrot, oleh karena itu peneliti menghentikan penelitiannya II pertemuan

2. Berikut ini akan dipaparkan pembahasan berdasarkan hasil temuan yang an dari tiap siklus dan tindakan.

Analisa tanggapan guru berdasarkan 1 pembelajaran dengan menerapkan metode PAIKEM ebagaimana yang dikemukakan berikut ini. Rekan guru yang bertindak langsung memberikan tanggapan yang positif yang telah dilaksanakan yaitu pembelajaran IPA dengan ibrot dapat meningkatkan kemampuan kreatif siswa, dan antusias dan senang ketika pembelajaran berlangsung.

Berdasarkan data dari wawancara dari peneliti, diperoleh hasil yaitu $100 \%$ siswa berpendapat bahwa metode PAIKEM Gembrot sangai pengetahuan dan lebih mudah siswa menjawab senang dengan metode PAIKEM Gembrot, karena siswa mereka inginkan, siswa pun dapat menggambar soal, sehingga pembelajaran terasa lebih ringan dan tidak. Berikut grafiknya :

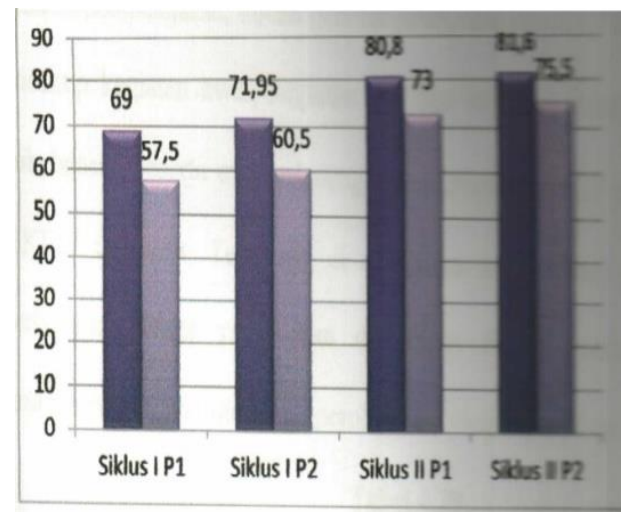

Grafik 1 Peningkatan Perolehan Nilai Akhir Kemampuan

Berdasarkan perolehan skor baik dalam Gembrot siklus I dan siklus II pada tabel di atas terlihai dalam kemampuan kreatif siswa dalam pembelajaran IPA dengan metode PAIKEM Gembrot. Peningkatan tersebut dapat nilai rata-rata kelas II.

Berdasarkan pelaksanaan tindakan yang dilaksanakan mulai dari siklus I dan siklus II dengan menerapkan metode PAIKEM Gembrot untuk meningkatkan ampuan kreatif siswa pada materi Lingkungan Alam di SD Negeri Manggarai Kecamatan Tebet Jakarta Selatan. Dalam penelitian ini peneliti memerlukan apan sebelum pelaksanaan pembelajaran. Perencanaan pembelajaran IPA penerapan metode PAIKEM Gembrot pada materi Lingkungan Alam ini wali dengan menganalisis kurikulum untuk mengetahui 
standar kompetensi dan kompetensi dasar yang akan diterapkan ke dalam RPP, menyusun RPP rta yang berisi standar kompetensi, kompetensi dasar, indikator pembelajaran.

\section{SIMPULAN}

Berdasarkan analisis data dan pembahasan sehingga penulis dapat simpulan dalam penelitian ini berkaitan dengan pereacamn, 11 Iri immm. tefl peningkatan kemampuan kreatif siswa dengan menerapkan metode PAIKEM gembrot.

Perencanaan pembelajaran Lingkungan Alam penulis menyusun beberapa . antara lain: 1) Peneliti mengamati kurikulum untuk mengetahui kompetensi yang akan disampaikan, 2) Menyusun atau merancang RPP (Rencana aan Pembelajaran) dengan penerapan metode PAIKEM Gembrot dalam belajaran Lingkungan Alam, 3) Menyiapkan media, 4) menyusun soal tes uraian yang mengacu kepada aspek-aspek penilaian berpikir kreatif, yakni an dalam berpikir dan mengungkapkan banyak gagasan dalam suatu ahan, 5) Menyusun kriteria penilaian soal. Pelaksanaan pembelajaran dalam penelitian ini mengacu pada skenario langkah-langkah pembelajaran yang tertera didalam RPP tiap siklusnya. " dari kegiatan awal, kegiatan inti dan kegiatan akhir. Berdasarkan hasil analisis pada bab 4, Penerapan PAIKEM Gembrot Meningkatkan Hasil Belajar Sains di Kelas II dinyatakan berhasil dilihat peningkatan nilai siswa dari hasil menjawab soal uraian. Berdasarkan hasil tanggapan guru dan siswa mengenai pembelajaran dengan menerapkan metode PAIKEM Gembrot juga RPP dan terlaksana dengan baik berdasarkan lembar observasi.

\section{DAFTAR PUSTAKA}

Ahmadi dan Amri. (2011). PAIKEM GEMBROT Pustakaraya.

Arikunto, S. (2011). Dasar-Dasar Evaluasi Pendidikan. Jakarta.

Badan Standar Nasional Pendidikan (BNSP). (2006). Kutucuum pendidikan Sekolah adasar mata pelajaran IP A SD/ MI. Jakarta: Depdbas.

Depdikna. (2006) Kurikulum 2006 Standar Kompetensi Mata Pelajaran. Jakarta: Depdiknas.

Dewi, M.R. (2012). Penerapan metode eksperimen untuk meningkatkan hasil belajar siswa pada pokok bahasan gaya dalam pembelajaran. Jurusan PGSD Bumi Siliwangi: Tidak Diterbitkan.

Fitrianawati, N.(2011). Penerapan PAIKEM Untuk Meningkatkan Hasil Belajar Siswa SD Dalam Pembelajaran IPA. Jurusan PGSD Bumi Siliwangi: Tidak Diterbitkan.

Kusnandar. 2008). Langkah Mudah Penelitian Tindakan Kelas Sebagai embangan Profesi Guru. Jakarta: PT Raja Grafindo Persada.

Kusumah dan Dwitagama. (2010). Mengenal Penelitian Tindakan Kelas. Jakarta: Indeks.

Makmun, A.S. (2002). Psikologi Kependidikan. Bandung: Rosdakarya.

Peraturan Pemerintah Republik Indonesia Nomer 19 Tahun 2005 Tentang Standar Pendidikan. Jakarta: Departemen Pendidikan Nasional.

Purwanto N. (2011). Psikologi Pendidikan. Bandung: Rosdakaiya.

Riswandi dkk. (2010). Metode Penelitian Pendidikan SD. Bandung: UPI Press.

Sadulloh, U. Dkk. (2007). Pedagogik. Bandung: Cipta Utama.

Sagala2007). Konsep Dan Makna Pembelajaran. Bandung: Alfabeta

Samatowa U (2010). Pembelajaran IPA di Sekolah Dasar. Jakarta: PT Indeks.

Sanjaya, W. (2010). Strategi Pembelajaran Berorientasi Standar Proses Pendidikan. Jakarta: Kencana. 
2158 Penerapan PAIKEM GEMBROT untuk meningkatkan hasil belajar sains di sekolah dasarMulyani Sabihi

Sukarjo dan Komarudin . (2010). Landasana Pendidikan Konsep dan Aplikasinya. Jakarta: PT Rajagripindo Persada.

Sudjana, N.(2009). Penilaian Hasil Proses Belajar Mengajar. Bandung: PT Remaja Rosdakarya

T.n 12). Pengertian Ilmu pengetahuan Alam dan Karakteristik Bidang Kajian Hmu IPA

Online). Dikutip http: //www.saijanaku.com/2012/09/pengertianilmu-pengetahuan-alam- dan.html (21 Febuari 2013)

Wahyudin U. Dkk. (2006). Evaluasi Pembelajaran SD. Bandung: UPI Press R. (2008). Metode penelitian tindakan kelas. Bandung: Remaja 